\title{
Impact of labile and recalcitrant carbon treatments on available nitrogen and plant communities in a semiarid ecosystem
}

\author{
I. C. Burke, ${ }^{1,4}$ E. E. Bontti, ${ }^{1}$ J. E. Barrett, ${ }^{2}$ P. N. Lowe, ${ }^{3}$ W. K. Lauenroth ${ }^{1}$ and R. Riggle ${ }^{3}$ \\ ${ }^{1}$ Haub School of Environment and Natural Resources, Department of Botany, Program in Ecology, and Department of Ecosystem \\ Science and Management, University of Wyoming, Laramie, Wyoming 82072 USA \\ ${ }^{2}$ Department of Biological Sciences, Virginia Technological University, Blacksburg, Virginia 24061 USA \\ ${ }^{3}$ Natural Resources Ecology Laboratory, Colorado State University, Fort Collins, Colorado 80523 USA
}

\begin{abstract}
In a 10-year study, we assessed the influence of five carbon $(\mathrm{C})$ treatments on the labile $\mathrm{C}$ and nitrogen $(\mathrm{N})$ pools of historically N-enriched plots on the Shortgrass Steppe Long Term Ecological Research site located in northeastern Colorado. For eight years, we applied sawdust, sugar, industrial lignin, sawdust + sugar, and lignin + sugar to plots that had received N and water additions in the early 1970s. Previous work showed that past water and $\mathrm{N}$ additions altered plant species composition and enhanced rates of nutrient cycling; these effects were still apparent 25 years later. We hypothesized that labile $\mathrm{C}$ amendments would stimulate microbial activity and suppress rates of $\mathrm{N}$ mineralization, whereas complex forms of carbon (sawdust and lignin) could enhance humification and lead to longer-term reductions in $\mathrm{N}$ availability. Results indicated that, of the five carbon treatments, sugar, sawdust, and sawdust + sugar suppressed $\mathrm{N}$ availability, with sawdust + sugar being the most effective treatment to reduce $\mathrm{N}$ availability. The year after treatments stopped, $\mathrm{N}$ availability remained less in the sawdust + sugar treatment plots than in the high- $\mathrm{N}$ control plots. Three years after treatments ended, reductions in $\mathrm{N}$ availability were smaller (40-60\%). Our results suggest that highly labile forms of carbon generate strong short-term $\mathrm{N}$ sinks, but these effects dissipate within one year of application, and that more recalcitrant forms reduce $\mathrm{N}$ longer. Sawdust + sugar was the most effective treatment to decrease exotic species canopy cover and increase native species density over the long term. Labile carbon had neither short- nor long-term effects on exotic species. Even though the organic amendments did not contribute to recovery of the dominant native species Bouteloua gracilis, they were effective in increasing another native species, Carex eleocharis. These results indicate that organic amendments may be a useful tool for restoring some native species in the shortgrass steppe, though not all.
\end{abstract}

Key words: Bouteloua gracilis; carbon addition; Carex eleocharis; exotic species; historic fertilization; lignin; sawdust; Shortgrass Steppe Long Term Ecological Research site; sugar.

\section{INTRODUCTION}

Anthropogenic alterations of the global nitrogen cycle have resulted in excess $\mathrm{N}$ in terrestrial ecosystems (Vitousek et al. 1997), contributing to soil acidification, cation leaching, eutrophication, increased trace gas production, the establishment of invasive plant species, and significant declines in biodiversity (Aber et al. 1989, Hobbs and Huenneke 1992, Vitousek et al. 1997). Yet few studies address the long-term impact of $\mathrm{N}$ additions in ecosystems (Spiegelberger et al. 2006, Clark et al. 2009). Even in relatively dry systems such as grasslands, many studies have demonstrated that increases in available $\mathrm{N}$ can result in the invasion and dominance of communities by exotic species with low nitrogen use efficiency (NUE), altering carbon (C) and $\mathrm{N}$ turnover rates and plant community composition over long-term time scales (Milchunas and Lauenroth 1995). In many

Manuscript received 4 January 2012; revised 28 September 2012; accepted 2 October 2012. Corresponding Editor: X. Xiao.

${ }^{4}$ E-mail: iburke@uwyo.edu cases, the N-rich (low C:N) litter of invasive species with low NUE creates plant-soil feedbacks of high decomposition and net $\mathrm{N}$ mineralization rates that promote high levels of $\mathrm{N}$ availability for many decades, thus maintaining soil conditions suitable for invasives (Vinton and Burke 1995, Maron and Jefferies 1999, Clark et al. 2009).

If increases in nutrient availability can facilitate the establishment and persistence of fast-growing weedy species, manipulating available $\mathrm{N}$ by lowering nutrient availability could potentially facilitate the reestablishment of native, usually slow-growing species (Blumenthal et al. 2003, Clark and Tilman 2010, Perry et al. 2010). Recent work that includes a wide variety of $C$ sources, as well as frequency and method of application (Corbin and D'Antonio 2004), has shown that C treatments can be very effective at stimulating $\mathrm{N}$ immobilization (Morghan and Seastedt 1999, Magill and Aber 2000, Szili-Kovacs et al. 2007, Clark and Tilman 2010). However, the effects of $\mathrm{N}$ reduction on invasive and native species have exhibited mixed results, 
with some research showing that increases in the prevalence of native species occur in parallel to a decrease in exotic species (Zink and Allen 1998, Blumenthal et al. 2003, Perry et al. 2004), and others reporting no increase in native species in spite of a decrease in exotic species (Morghan and Seastedt 1999, Alpert and Maron 2000). Other studies found no effect of $\mathrm{C}$ addition on exotic or native species (Paschke et al. 2000, Cione et al. 2002), despite decreased N availability. Therefore, the reduction of exotic species and the recovery of native species is complex (Perry et al. 2010), and likely influenced by numerous factors including: rate of C applications (Blumenthal et al. 2003), traits of the resident plant species (Lowe et al. 2002, Eschen et al. 2006), composition of the seed bank (Cione et al. 2002), and water availability (Blumenthal 2009).

Locations that have had a long-term history of enriched $\mathrm{N}$ and invasive species represent an ideal opportunity for testing the efficacy of $\mathrm{C}$ compounds in breaking the plant-soil feedbacks that promote and maintain invasive species. Previous studies have generally focused on microbial immobilization as a short-term (i.e., 1-3 year) sink for $\mathrm{N}$; to our knowledge no study has thus far sought to implement and study long-term remediation of enhanced $\mathrm{N}$ availability, particularly in systems with a multiple-decade history of enriched $\mathrm{N}$ conditions.

We are interested in processes that result in the longterm immobilization of soil N. Soil scientists have recognized the existence of chemical reactions between ammonia $\left(\mathrm{NH}_{4}^{+}\right)$and organic matter since 1942 , when Mattson and Koutler-Andersson (1942, 1943) (Nõmmik 1970), posed the hypothesis that $\mathrm{NH}_{4}{ }^{+}$capture accounts for a significant portion of $\mathrm{N}$ accumulation in humus. Since that time, many studies have shown that substantial amounts of fertilizer $\mathrm{N}$ are chemically "fixed" by the phenolic components of humus or stabilized within the interlattices of 2:1 clay minerals (Burge and Broadbent 1961, Mortland and Wolcott 1965, Foster et al. 1985, Paul and Clark 1989). However, the original hypothesis of Mattson and Koutler-Andersson has been largely ignored by the ecological community concerned with soil $\mathrm{N}$ dynamics. In ecological studies, previous work has indicated that between $10 \%$ and $50 \%$ of added ${ }^{15} \mathrm{~N}$ is lost to a soil organic form (Schimel and Firestone 1989, Stevenson and He 1990, Delgado et al. 1996), a loss that can occur extremely rapidly, suggesting chemical (nonbiological) fixation (Johnson 1992, Barrett et al. 2002). Though soils apparently retain significant quantities of added $\mathrm{N}$ via chemical fixation processes, we understand little about these processes, and they are not included in the most widely accepted ecosystem models. This limits our capabilities to predict the effects of chronic N loading on terrestrial ecosystems (Johnson 1992, Emmett 2007).

To address questions related to reducing $\mathrm{N}$ availability in grasslands, we initiated an N-reduction study on the Shortgrass Steppe Long Term Ecological Research site (information available online). ${ }^{5}$ Our objective was to assess the potential for reducing available $\mathrm{N}$ pools in historically nutrient-enriched soils via either sequestration in refractory pools of organic matter (e.g., humic compounds) or more ephemeral mechanisms through microbial immobilization. Barrett et al. (2002) reported that soil $\mathrm{C}$ increased the $\mathrm{N}$ immobilization potential of soils in laboratory incubations, and that abiotic processes represent from $4 \%$ to $40 \%$ of total $\mathrm{N}$ incorporation into organic matter. We still do not know the importance of these processes in the natural environment, or if excess $\mathrm{N}$ availability can be stabilized by manipulating $\mathrm{C}$ availability.

In this paper, we report the results of a 10 -year study examining the efficacy of $\mathrm{C}$ treatments on $\mathrm{N}$ availability and plant community composition, particularly with respect to the relative abundance of native and exotic species. We address the following questions: (1) Do C additions significantly reduce inorganic $\mathrm{N}$ availability? (2) Is there a difference in the magnitude and duration of the effects of adding labile and nonlabile sources of $\mathrm{C}$ ? (3) Do reductions in $\mathrm{N}$ availability influence the relative abundances of exotic and native species? We hypothesized that more labile C compounds (i.e., sucrose) would reduce $\mathrm{N}$ availability by stimulating microbial growth and immobilization of $\mathrm{N}$ on a short-term basis because the microbial consumption of simple compounds should not contribute to the development of recalcitrant organic matter. In contrast, we expected that more recalcitrant forms of $\mathrm{C}$ (i.e., cellulose and lignin) would increase the high molecular mass compounds necessary to facilitate condensation reactions and initiate longerterm stabilization of $\mathrm{N}$ than microbial immobilization alone. We further hypothesized that $\mathrm{C}$ addition would decrease the density and cover of exotic species, and contribute to an associated increase in native species because of the influence of $\mathrm{C}$ on the mechanisms of $\mathrm{N}$ retention described previously. Finally, we hypothesized that sugar additions would have a short-term effect on the density and cover of exotic and native species, due to microbial immobilization, whereas the more recalcitrant C substrates would have a longer-term effect on the density and cover of exotic species, because of a longterm chemical fixation and removal of available $\mathrm{N}$.

\section{Methods \\ Site description}

Our study plots are located in the piedmont of northeastern Colorado, $\sim 40 \mathrm{~km}$ south of Cheyenne, Wyoming (40 $49^{\prime} \mathrm{N}$ latitude, $104^{\circ} 46^{\prime} \mathrm{W}$ longitude), on the Central Plains Experimental Range (CPER). The location is within the Shortgrass Steppe Long Term Ecological Research Project research site (SGS-LTER) (Lauenroth and Burke 2008). The average elevation is $1650 \mathrm{~m}$ (5400 feet). The experiment was conducted

\footnotetext{
${ }^{5}$ http://sgs.cnr.colostate.edu/
} 
within a fenced enclosure on a level upland. Prior to the fencing in 1969, the area had been lightly grazed by cattle for at least 10 years (Lauenroth et al. 1978).

Long-term mean monthly temperatures range from $-4^{\circ} \mathrm{C}$ to $22^{\circ} \mathrm{C}$ seasonally, and have a daily average maximum-minimum range of $17^{\circ} \mathrm{C}$. Annual precipitation at the CPER has averaged $322 \mathrm{~mm}$ over the past 51 years and ranged between 107 and $588 \mathrm{~mm}$. Approximately $70 \%$ of the mean annual precipitation occurs during the April to September growing season (Lauenroth et al. 1978). The dominant plant species in the shortgrass steppe is the perennial bunchgrass, Bouteloua gracilis (H.B.K.) Lag. ex Griffiths., which on undisturbed sites accounts for up to $90 \%$ of the plant basal cover (Lauenroth 2008). Other common species include Buchloë dactlyoides (Nutt.) Engelm., a perennial grass; Artemisia frigida Willd., a dwarf shrub; Carex eleocharis L. Bailey, a sedge; Sphaeralcea coccinea (Pursh) Rydb., a forb; and Opuntia polyacantha Haw., a succulent (nomenclature follows Great Plains Flora Association, McGregor and Barkley [1986]).

\section{Experimental design}

We established six $\mathrm{C}$ treatments on a preexisting water and $\mathrm{N}$ addition experiment, which was initiated in 1970. The intent of this historical experiment was to assess the influence of additional water and $\mathrm{N}$ availability on the structure and function of a native shortgrass steppe ecosystem (Lauenroth et al. 1978). These historical treatments consisted of a factorial combination of $\mathrm{N}$ and water applications (control, + water, + nitrogen, and + nitrogen and water [NW]), replicated in two 1-ha blocks. Application of these treatments began in 1970 and continued through 1975. Irrigated plots received sufficient water additions to maintain water potential at a depth of $10 \mathrm{~cm}$ between 0 and $-0.08 \mathrm{MPa}$ from 1 May to 1 September, and resulted in water additions of 460 to $710 \mathrm{~mm} \mathrm{H}_{2} \mathrm{O} / \mathrm{yr}$ (Lauenroth et al. 1978). Nitrogen fertilizer $\left(100-150 \mathrm{~kg} \mathrm{NH} \mathrm{NO}_{3} \cdot \mathrm{ha}^{-1} \cdot \mathrm{yr}^{-1}\right)$ was added to maintain a difference between fertilized and unfertilized plots of at least $50 \mathrm{~kg} /$ ha of soil mineral $\mathrm{N}$. Water and $\mathrm{N}$ additions ceased in 1975, and except for regular soil and vegetation sampling, have remained undisturbed by further manipulation until 1997. These treatments resulted in consistently higher available nitrogen and domination by exotic invasive species, which have persisted since the treatments ceased in 1975 (Milchunas and Lauenroth 1995, Vinton and Burke 1995). The most abundant exotic species are Kochia scoparia, Salsola iberica, Sisymbrium altissimum, and Cirsium arvense.

Beginning in 1997, we overlaid six C-amendment treatments on both blocks of these historical water and $\mathrm{N}$ manipulation plots in a split-plot design to assess the influence of various $\mathrm{C}$ substrates on $\mathrm{N}$ availability and plant community composition in historically $\mathrm{N}$ - and water-enriched ecosystems. We randomly located three transects (each $3 \times 18 \mathrm{~m}$ ) within each 1-ha historic water plus nitrogen (NW) treatment; each one of these transects was divided evenly into six $9-\mathrm{m}^{2}$ carbon treatment plots, for a total of 36 subplots (two NW treatments $\times$ six $\mathrm{C}$ treatments $\times$ three transects). We randomly assigned each of the six subplots in each transect one of the six new carbon treatments: control, sugar, lignin, sawdust, lignin + sugar, and sawdust + sugar. The additions provided $350 \mathrm{~g}$ carbon $\cdot \mathrm{m}^{-2} \cdot \mathrm{yr}^{-1}$, resulting in $1061 \mathrm{~g} / \mathrm{m}^{2}$ of lignin, $777 \mathrm{~g} / \mathrm{m}^{2}$ sawdust, and $833 \mathrm{~g} / \mathrm{m}^{2}$ sugar being added to the subplots from 1998 to 2004. Native total organic $\mathrm{C}$ content in the surface 10 $\mathrm{cm}$ of soils is $\sim 1700 \mathrm{~g} \mathrm{C} / \mathrm{m}^{2}$, most of which is in recalcitrant form (Burke et al. 1995). The sugar applications were hand broadcast in 10 even increments from April to September, while the lignin and sawdust were added only once a year, in April. In 1997, the lignin and sawdust applications were added in September at $75 \%$ of the above values, and the sugar was applied once during the same time at $10 \%$ of the total. We obtained lignin in a purified form under the trade name Indulin AT from Westvaco Chemical Division (Charleston Heights, South Carolina. USA). We used aspen sawdust from Delta Timber Company (Delta, Colorado, USA), and we purchased sugar in bulk as table sugar from a variety of sources.

Following 2004, we ceased the treatments, to determine the difference among carbon sources in their persistence in influencing $\mathrm{N}$ availability and vegetation composition. Thus, treatments were applied for eight years (1997-2004), and followed for an additional three years. In this study, we focus our analysis on the NW treatments, because they represent the highest level of $\mathrm{N}$ availability for pursuing our question about effectiveness and persistence of carbon treatments.

\section{Nitrogen availability assessment}

During one month each summer from 1998 to 2000, and from 2003 to 2007, we estimated in situ rates of net nitrogen mineralization. During the first three years, we used a core incubation method (Hook and Burke 1995) to estimate $\mathrm{N}$ mineralization. Three aluminum cores (17.5 cm long and $5 \mathrm{~cm}$ wide) per subplot per treatment were pushed into soils, removed temporarily, and the 2.5 $\mathrm{cm}$ of soil was replaced with a nylon mesh bag containing anion and cation exchange resins. The core was returned to the soil and incubated for 30 days. At the same time, a separate $15-\mathrm{cm}$ core was removed for analysis for $\mathrm{NH}_{4}{ }^{+}$and $\mathrm{NO}_{3}{ }^{-}$, by extracting the soil with $2 \mathrm{~mol} / \mathrm{L} \mathrm{KCl}$, and analyzing the extracts on an Alpkem Autoanalyzer (Pulse Instruments Limited, Saskatoon, Saskatchewan, Canada). Resins were extracted similarly. In situ net $\mathrm{N}$ mineralization was calculated as the difference between initial and final inorganic $\mathrm{N}$ in the soils, added to the $\mathrm{N}$ extracted from the resin. Because $>95 \%$ of the inorganic $\mathrm{N}$ is $\mathrm{NO}_{3}{ }^{-}$, we have lumped $\mathrm{NO}_{3}{ }^{-}$and $\mathrm{NH}_{4}^{+}$for this study. For the latter years of the study, we incubated resin probes (PRS probes, Western Agricultural Innovations, Saskatoon, Saskatchewan, Canada) to estimate the relative amount of $\mathrm{NH}_{4}{ }^{+}$ 
and $\mathrm{NO}_{3}{ }^{-}$available to plants. We placed one pair of probes (one anion and one cation probe) per subplot per treatment, and left them in place for $\sim 30$ days (sometimes for longer, depending upon precipitation), after which we extracted them from the soil and took them to the laboratory for $\mathrm{N}$ extraction. Thirty-day incubations with resins do not saturate the capacity of the resins (Hook and Burke 2000, McCulley et al. 2009, Bontti et al. 2011). Inorganic $\mathrm{N}$ was extracted with 25 $\mathrm{mL}$ of $0.5 \mathrm{~mol} / \mathrm{L} \mathrm{HCl}$ for one hour in a ziplock bag in an orbital shaker, and we analyzed the extractant for $\mathrm{NH}_{4}{ }^{+}$ and $\mathrm{NO}_{3}{ }^{-}$using an Alpkem Autoanalyzer. Because the resin probes sorb $\mathrm{N}$ from an undetermined volume of soil (Johnson et al. 2004), $\mathrm{NH}_{4}{ }^{+}$and $\mathrm{NO}_{3}{ }^{-}$are reported on a per square centimeter of probe basis, allowing for comparison across treatments but not for areal estimates of $\mathrm{N}$ from soil. Our focus for this study was the differences among treatments during each year, and not among years or methods.

\section{Vegetation sampling}

In August or September from 1997 to 2007, we recorded density and canopy cover by species within a centrally located $1-\mathrm{m}^{2}$ quadrat within each $9-\mathrm{m}^{2}$ treatment plot. Exotic density (number of exotic plant individuals per square meter) was calculated from the density data. We determined canopy cover by species using Daubenmire (1959) quadrat canopy cover classes and calculated exotic and native species canopy cover by summing cover by species in each category.

\section{Statistical analyses}

The $\mathrm{N}$ availability, plant density, and canopy cover were analyzed between the "true control" (no nitrogen or carbon treatments) and within the historic NW plots, comparing carbon treatments in a complete randomized block analysis with the Proc Mixed Procedure in SAS (SAS Institute 1989). There were two blocks where $\mathrm{N}$ and water were applied 3-4 decades ago and three subsamples per block where the six $\mathrm{C}$ treatments were randomly applied. Fisher's test of least significant difference (LSMEANS) was used to compare the means, and means were considered different at the 0.05 significance level. Since C treatments lasted eight years (from 1997 to 2004), we considered 2004 as an example of short-term effect (right after the cessation of carbon treatments), and we used 2007 as an example of longterm effect (after 10 years of the initial carbon applications). As we have no record of canopy cover in 2004, we used 2006 as the short-term comparison for canopy cover.

\section{RESUlts AND Discussion}

\section{Available nitrogen}

Historical $\mathrm{N}$ additions had a significant effect upon $\mathrm{N}$ availability, estimated as $\mathrm{N}$ mineralization using the core incubation technique and the cation-anion resin exchange probe technique. $\mathrm{N}$ mineralization was consis- tently highest in soils collected from the historical NW plots (Fig. 1b) where $\mathrm{C}$ was not applied, and these differences did not appear to correspond with interannual variability in precipitation (Fig. 1a, b). This shows that the legacy of $\mathrm{N}$ additions on microbial communities and nitrogen availability was still apparent several decades after cessation of nutrient inputs. Vinton and Burke (1995) and Bontti et al. (2011) reported similar results for these soils in a previous study, in which they found that $\mathrm{N}$ mineralization and total soil $\mathrm{C}$ and $\mathrm{N}$ were elevated in historical NW plots relative to control plots.

Sugar additions significantly reduced the dominant form of available $\mathrm{N}, \mathrm{NO}_{3}{ }^{-}$, during the years of treatment (1998-2004) relative to both the true control treatment (no nitrogen or carbon added), and the NWcontrol (historically fertilized). The year following the cessation of treatments, the sugar treatment rebounded to higher levels than the true control $(>250 \%$ of control), and significantly larger than the NW-control. $\mathrm{N}$ mineralization in the sugar treatment remained high and insignificantly different from the NW-control for the two years (2006-2007) following.

Sawdust alone and in combination with sugar decreased $\mathrm{N}$ mineralization, with much larger impacts in the combined treatment. These results supported our general hypothesis that changes in $\mathrm{C}$ substrate availability can suppress $\mathrm{N}$ availability, likely by enhancing microbial activity (Jonasson et al. 1996, Török et al. 2000). By 2004, the combined effect of sugar and sawdust on reducing $\mathrm{N}$ availability was significantly greater than that of sugar alone, suggesting that the more recalcitrant $\mathrm{C}$ source (sawdust) added additional immobilization potential, whether through biotic or abiotic processes such as those we have demonstrated in the laboratory (Barrett et al. 2002). The quantity of $\mathrm{C}$ added to these combined sawdust + sugar treatments was the same as the sawdust alone and the sugar alone. Possibly, the rate of humification was enhanced by the presence of the easily available energy source for microbial activity, sugar, leading to more condensation reactions that chemically "fix" the $\mathrm{N}$ (Broadbent et al. 1960).

According to our hypothesis, if the sawdust + sugar treatment resulted in increased $\mathrm{N}$ capture by humus, we expected this sink to be essentially permanent. Sugar treatments rebounded within one year, and sawdust treatment effects persisted longer.

Notably, lignin and lignin + sugar were not effective in suppressing $\mathrm{N}$ availability at short or long timescales (Fig. 2). Overall lignin did not have a significant influence over $\mathrm{N}$ availability. While recalcitrant pools of soil organic matter such as lignin are humus precursors that can stabilize $\mathrm{N}$ over century to millennial time scales (Stevenson 1994), they may stabilize N at relatively slow rates and hence not represent large $\mathrm{N}$ sinks relative to $\mathrm{N}$ availability. An alternative explanation of lignin's effect is that this substrate, because it is hydrophobic and as it was cast on the soil surface, might 


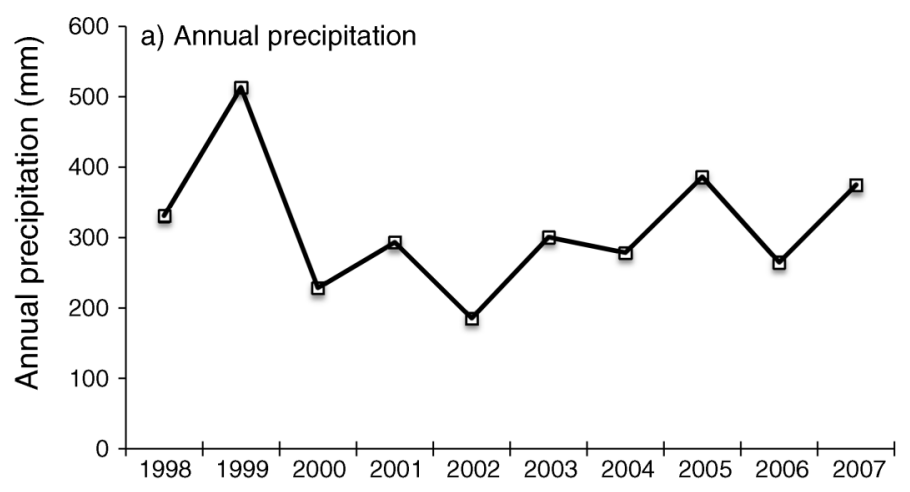

b) $\mathrm{N}$ mineralization in control and historically fertilized plots
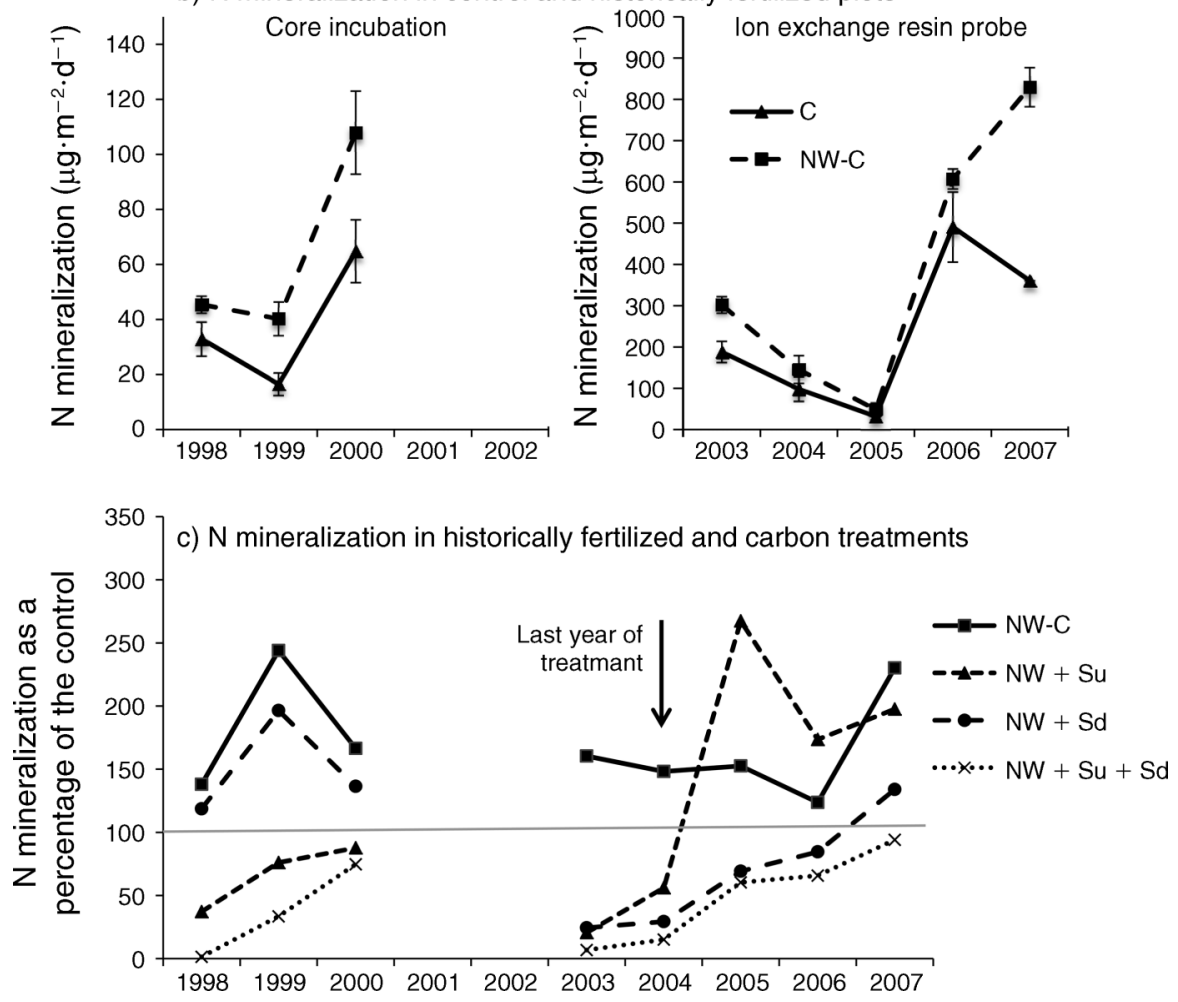

FIG. 1. (a) Annual precipitation at the Shortgrass Steppe Long Term Ecological Research Station, northeastern Colorado, USA, from 1998 to 2007. Summer precipitation, the dominant input, had very similar trends. (b) Estimated in situ net nitrogen mineralization for the true control $(\mathrm{C}$, no $\mathrm{N}$ or carbon treatments ever added) and the historically fertilized and water treatment (NW-C, no carbon treatments) during the same period, using two techniques, a core incubation method from 1998 to 2000 (left $y$ axis), and an ion exchange resin probe for 2003-2012 (right $y$-axis). Values are means \pm SD, and all years showed significant differences between the treatments except for 2005. (c) N mineralization in the carbon-treated plots (Su is sugar; Sd is sawdust) within the historically fertilized (NW, nitrogen and water) plots, all as a percentage of the $\mathrm{N}$ mineralization measured in the true control treatment [C, from panel (b)] (shown in the gray line representing 100\%). There were significant treatment effects in all years except 2007.

have had the effect of decreasing plant growth, thus decreasing $\mathrm{N}$ uptake and allowing inorganic $\mathrm{N}$ levels to persist.

We had three years of post-treatment data (2005 to 2007) to evaluate the persistence of eight years of carbon treatments as $\mathrm{N}$ sinks. The data indicate that, indeed, sugar treatments lost their effectiveness after three years, but contrary to our expectations, the sawdust treatments (both alone and in combination with sugar) also failed to maintain lower $\mathrm{N}$ availability than the control after three years. It is unlikely that this effect was related to interannual variability in precipitation (Fig. 1a). N availability in the carbon-treated areas increased across the years after treatments ended, and differences among treatments decreased. Therefore, the $\mathrm{C}$ sources and concentrations used in this experiment, whether labile or recalcitrant $\mathrm{C}$ sources, showed only a transient influence on subsequent rates of $\mathrm{N}$ cycling. Eschen et al. (2007), 


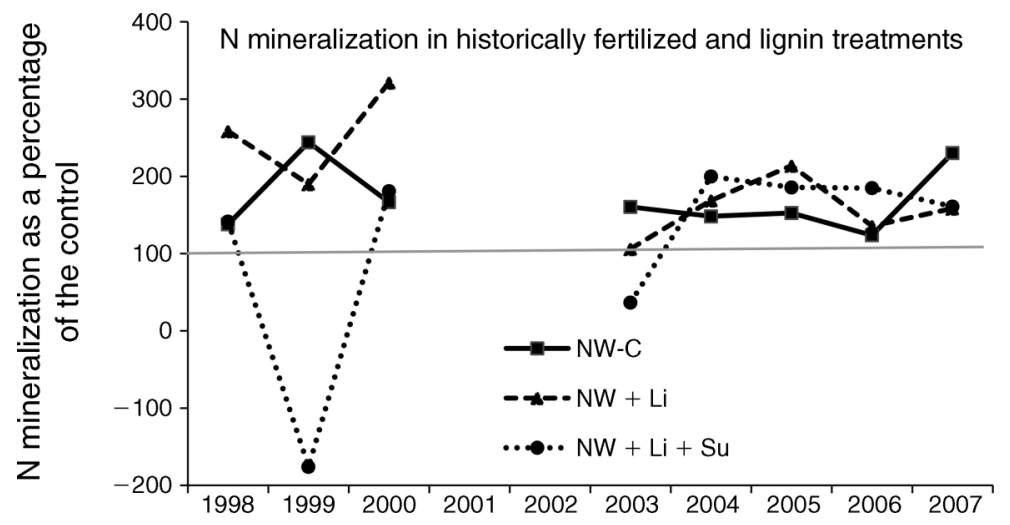

FIG. 2. Net $\mathrm{N}$ mineralization in the lignin and lignin $+\operatorname{sugar}(\mathrm{Li}+\mathrm{Su})$ treated plots within the historically fertilized $(\mathrm{NW})$ plots, all as a percentage of the $\mathrm{N}$ mineralization measured in the true control treatment $(\mathrm{C}$, from Fig. $1 \mathrm{~b}$ ) (shown in the gray line representing 100\%). Neither of the lignin treatments differed from NW controls plots (no lignin added).

using higher levels of $\mathrm{C}$, found some persistence of $\mathrm{C}$ effects, but only measured after one year. This should be taken into account in vegetation management so that land managers can seed native species during the window of opportunity provided by low available $\mathrm{N}$ and suppressed exotics, to maintain low $\mathrm{N}$ availability. Concentrations of $\mathrm{C}$ higher than those used in our experiment might also be more useful in the long term (Blumenthal et al. 2003, Eschen et al. 2007). The lack of soil disturbance throughout our experiment is likely an important contributing factor; $\mathrm{C}$ was neither mixed into subsurface soil for more rapid immobilization, nor were perennial plants disturbed.

\section{Plant density and canopy cover response}

Our results regarding plant density and canopy cover were not as simple as our hypotheses predicted. The addition of sugar did not affect exotic species density or cover in the short or long term, whereas the addition of humus precursors alone (i.e., sawdust) or in combination with sugar (i.e., lignin + sugar and sawdust + sugar) reduced both the density (Table 1) and canopy cover (Table 2) of exotic species in the short term. Canopy cover of exotic species remained low over the long term following recalcitrant $\mathrm{C}$ additions, but we did not detect long-term effects on exotic species density. Interestingly, we detected a long-term increased density of one native species, Carex eleocharis, which occurred despite the lack of long-term effect of sawdust + sugar on exotic species density. As with most shortgrass steppe native species, most of C. eleocharis biomass, and C storage, is belowground. However, C. eleocharis root lignin: N ratio is lower than that of the dominant Bouteloua gracilis (Vinton and Burke 1995). Given that lignin content is an important control over litter decomposition in this ecosystem (Bontti et al. 2009), further studies should take into account the effect of $C$. eleocharis abundance in the shortgrass steppe $\mathrm{N}$ cycling.

Sawdust and sawdust + sugar treatments initially suppressed exotics by $60 \%$ and $80 \%$, respectively, which occurred parallel to a five- to ninefold rise in the native species C. eleocharis density. Interestingly, Clark and

TABLE 1. Mean (with SE in parentheses) response of plant density to carbon treatments on historic nitrogen plus water (NW) plots at the Shortgrass Steppe Long Term Ecological Research site, northeastern Colorado, USA.

\begin{tabular}{|c|c|c|c|c|c|c|}
\hline \multirow[b]{3}{*}{ Treatments } & \multicolumn{6}{|c|}{ Plant density (individuals $/ \mathrm{m}^{2}$ ) } \\
\hline & \multicolumn{3}{|c|}{2004} & \multicolumn{3}{|c|}{2007} \\
\hline & $\begin{array}{l}\text { Exotic } \\
\text { species }\end{array}$ & $\begin{array}{c}\text { Carex } \\
\text { eleocharis }\end{array}$ & $\begin{array}{c}\text { Bouteloua } \\
\text { gracilis }\end{array}$ & $\begin{array}{l}\text { Exotic } \\
\text { species }\end{array}$ & $\begin{array}{c}\text { Carex } \\
\text { eleocharis }\end{array}$ & $\begin{array}{c}\text { Bouteloua } \\
\text { gracilis }\end{array}$ \\
\hline NW-control & $103^{\mathrm{a}}(21)$ & $9^{\mathrm{ab}}(6)$ & $0.2(0.2)$ & $274(82)$ & $71^{\mathrm{a}}(26)$ & $1(1)$ \\
\hline Lignin & $66^{\mathrm{ab}}(14)$ & $5^{\mathrm{a}}(5)$ & $0.0(0.0)$ & $250(60)$ & $12^{\mathrm{a}}(8)$ & $<1(<1)$ \\
\hline Lignin + sugar & $43^{\mathrm{bc}}(14)$ & $13^{\mathrm{b}}(4)$ & $1(0.4)$ & $139(20)$ & $16^{\mathrm{a}}(8)$ & $1(<1)$ \\
\hline Sugar & $82^{\mathrm{ac}}(16)$ & $43^{c}(16)$ & $0.5(0.3)$ & $230(30)$ & $76^{\mathrm{a}}(29)$ & $1(1)$ \\
\hline Sawdust & $32^{\mathrm{bc}}(10)$ & $46^{\mathrm{c}}(14)$ & $1(0.4)$ & $112(34)$ & $108^{\mathrm{ac}}(75)$ & $1(<1)$ \\
\hline Sawdust + sugar & $19^{\mathrm{b}}(7)$ & $82^{\mathrm{c}}(22)$ & $1(0.5)$ & $159(77)$ & $238^{\mathrm{bc}}(79)$ & $1(1)$ \\
\hline
\end{tabular}

Notes: Carbon treatments were applied to sites that had been fertilized and watered heavily from 1970 to 1975 ; the carbon treatments were applied from 1997 to 2004; thus, the 2004 results show short-term responses to eight years of C additions, and the 2006 and 2007 results show the persistence of the treatments two and three years after cessation. Means in the same column with the same letter are not significantly different at $P=0.05$. Columns with no letters indicate no significant difference among treatments at $P=0.05$. 
TABLE 2. Mean (with SE in parentheses) response of plant canopy cover to carbon treatments on historic nitrogen plus water (NW) plots at the Shortgrass Steppe Long Term Ecological Research site.

\begin{tabular}{|c|c|c|c|c|c|c|}
\hline \multirow[b]{3}{*}{ Treatments } & \multicolumn{6}{|c|}{ Canopy cover (\%) } \\
\hline & \multicolumn{3}{|c|}{2006} & \multicolumn{3}{|c|}{2007} \\
\hline & $\begin{array}{l}\text { Exotic } \\
\text { species }\end{array}$ & $\begin{array}{c}\text { Carex } \\
\text { eleocharis }\end{array}$ & $\begin{array}{c}\text { Bouteloua } \\
\text { gracilis }\end{array}$ & $\begin{array}{l}\text { Exotic } \\
\text { species }\end{array}$ & $\begin{array}{c}\text { Carex } \\
\text { eleocharis }\end{array}$ & $\begin{array}{c}\begin{array}{c}\text { Bouteloua } \\
\text { gracilis }\end{array} \\
\text { to }\end{array}$ \\
\hline NW-control & $6^{\mathrm{a}}(2)$ & $3(1)$ & $1(1)$ & $25^{\mathrm{a}}(8)$ & $5(1)$ & $2(2)$ \\
\hline Lignin & $6^{a}(2)$ & $1(0.5)$ & $0.4(0.4)$ & $24^{\mathrm{a}}(7)$ & $2(1)$ & $5(2)$ \\
\hline Lignin + sugar & $6^{a}(2)$ & $2(0.5)$ & $2(1)$ & $33^{\mathrm{a}}(8)$ & $3(1)$ & $<1(<1)$ \\
\hline Sugar & $8^{a}(2)$ & $3(1)$ & $0.4(0.4)$ & $24^{a}(4)$ & $5(2)$ & $3(2)$ \\
\hline Sawdust & $6^{a}(3)$ & $5(3)$ & $1(0.5)$ & $16^{\mathrm{a}}(5)$ & $10(6)$ & $2(2)$ \\
\hline Sawdust + sugar & $1^{\mathrm{b}}(<1)$ & $11(5)$ & $1(1)$ & $9^{b}(4)$ & $16(6)$ & $3(2)$ \\
\hline
\end{tabular}

Notes: Carbon treatments were applied to sites that had been fertilized and watered heavily from 1970 to 1975 ; the carbon treatments were applied from 1997 to 2004; thus, the 2004 results show responses to eight years of C additions, and the 2006 and 2007 results show the persistence of the treatments two and three years after cessation. Means in the same column with the same letter are not significantly different at $P=0.05$. Columns with no letters indicate no significant difference among treatments at $P=$ 0.05 .

Tilman (2010) found similar responses of native Carex species to carbon additions. Furthermore, even though we did not detect a long-term effect of sawdust + sugar on exotic density, in 2007 C. eleocharis density was still three times higher than in the control, illustrating that a short-term opportunity for increased growth of a rhizomatous native species could provide sufficient time for its recovery.

We hypothesized that $\mathrm{C}$ treatments would lower $\mathrm{N}$ availability, and as a consequence, increase the competitive advantage of native species. Although some of the $\mathrm{C}$ treatments did increase native species density and cover, they did not affect canopy cover or density of the normally dominant shortgrass steppe native B. gracilis, which is a bunchgrass that has a large effect on the spatial distribution of nutrients (Hook et al. 1991), through concentrating nutrients beneath it, relative to interspaces. Although high $\mathrm{C}$ additions increase the biomass of some native prairie species in other ecosystems through competitive release (Blumenthal et al. 2003, Clark and Tilman 2010), other species such as Bouteloua curtipendula experience little release even under very high $\mathrm{C}$ additions (i.e., $3000 \mathrm{~g} \mathrm{C} / \mathrm{m}^{2}$ ); native grasses in Californian grasslands (Alpert and Maron 2000) and in mixed-grass prairie in Colorado (Morghan and Seastedt 1999) also have not responded to similar treatments. The lack of response of some native species could also be the result of low seed rain compared to that of other native or exotic species (Alpert and Maron 2000). Furthermore, B. gracilis is a slow-growing perennial grass with infrequent recruitment events, and its recovery from other types of disturbance can take up to 50 years (Coffin et al. 1996). Therefore, the timescale of our observations might not have been long enough to detect recovery of this species, or our treatments may not have persisted long enough.

Our study indicates that the addition of $\mathrm{C}$ to soils as a restoration method intended to reduce or eliminate exotic species in favor of native vegetation is only partially effective in the shortgrass steppe, at least over a 10 -year period. The idea of decreasing available $\mathrm{N}$ to reduce exotic species relies heavily on the oft-made assumption that all exotic species have a strong response to high $\mathrm{N}$ and therefore may be harmed disproportionately as compared to native species under low-N conditions. However, not all exotic species have a stronger response to increased $\mathrm{N}$ compared to native species (Lowe et al. 2002, Blumenthal et al. 2003, Corbin and D'Antonio 2004), so the effectiveness of decreasing $\mathrm{N}$ to decrease exotics may depend on the specific characteristics of the exotic species present, i.e., the degree of nitrophilia (Blumenthal et al. 2003), the species composition of the site to be treated (Corbin and D'Antonio 2004), and the seed bank composition (Cione et al. 2002). Similarly, the response of native species to $\mathrm{N}$ reduction methods may be highly dependent on the characteristics of these species, including reproductive form, seed dispersal, and growth rates.

\section{Conclusion}

Elevated $\mathrm{N}$ availability had a significant influence over community composition and nutrient cycling for $>25$ years after cessation of increased $\mathrm{N}$ inputs. We found that $\mathrm{C}$ amendments, particularly sawdust and sawdust + sucrose, reduced $\mathrm{N}$ availability. Over a decade of monitoring, we determined that such $\mathrm{C}$ treatments have only a short-term effect in remediating $\mathrm{N}$ additions, although effects on vegetation are more persistent. Consistent $\mathrm{C}$ additions or higher $\mathrm{C}$ concentrations could be necessary to achieve persistent effects. We did not find evidence that addition of recalcitrant $\mathrm{C}$ substrates resulted in abiotic or long-term reductions in the availability of $\mathrm{N}$. Given pervasive and chronic $\mathrm{N}$ saturation in many temperate ecosystems, these results have important ramifications for restoration ecology and may provide insights into methods to ameliorate the effects of elevated $\mathrm{N}$ on soil nutrient pools and plant community structure in $\mathrm{N}$-saturated environments. 


\section{ACKNOWLEDGMENTS}

This work was supported by the National Science Foundation Research Experience for Undergraduates program, the Shortgrass Steppe Long Term Ecological Research Site (DEB No. 9632852), and the National Science Foundation Grant No. DEB 9707296. We thank Nicole Kaplan, Mark Lindquist, Judy Hendryx, Laurel Hartley, Rebecca McCulley, Dani-Ella Betz, Peter Adler, John Bradford, David Smith, Daniel Spiess, Brian Ford, Anne Jakle, and Laura Peck for assistance in the lab, field, and editing process.

\section{Literature Cited}

Aber, J. D., K. J. Nadelhoffer, P. Steudler, and J. M. Melillo. 1989. Nitrogen saturation in northern forest ecosystems. BioScience 39:378-386.

Alpert, P., and J. L. Maron. 2000. Carbon addition as a countermeasure against biological invasion by plants. Biological Invasions 2:33-40.

Barrett, J. E., D. W. Johnson, and I. C. Burke. 2002. Abiotic nitrogen uptake in semiarid grassland soils of the US Great Plains. Soil Science Society of America Journal 66:979-987.

Blumenthal, D. M. 2009. Carbon addition interacts with water availability to reduce invasive forb establishment in a semiarid grassland. Biological Invasions 11:1281-1290.

Blumenthal, D. M., N. R. Jordan, and M. P. Russelle. 2003. Soil carbon addition controls weeds and facilitates prairie restoration. Ecological Applications 13:605-615.

Bontti, E. E., I. C. Burke, and W. K. Lauenroth. 2011 Nitrogen partitioning between microbes and plants in the shortgrass steppe. Plant and Soil 342:445-457.

Bontti, E. E., J. P. Decant, S. M. Munson, M. A. Gathany, A. Przeszlowska, M. L. Haddix, S. Owens, I. C. Burke, W. J. Parton, and M. E. Harmon. 2009. Litter decomposition in grasslands of Central North America (US Great Plains). Global Change Biology 15:1356-1363.

Broadbent, F. E., W. D. Burge, and T. Nakashima. 1960 Factors influencing the reaction between ammonia and soil organic matter. Transactions of the Seventh International Congress of Soil Science 2:509-516.

Burge, W. D., and F. E. Broadbent. 1961. Fixation of ammonia by organic soils. Soil Science Society of America Proceedings 25:199-204.

Burke, I. C., W. K. Lauenroth, and D. P. Coffin. 1995. Soil organic matter recovery in semiarid grasslands: implications for the conservation reserve program. Ecological Applications 5:793-801.

Cione, N. K., P. E. Padgett, and E. B. Allen. 2002. Restoration of a native shrubland impacted by exotic grasses, frequent fire, and nitrogen deposition in southern California. Restoration Ecology 10:376-384

Clark, C. M., S. E. Hobbie, R. Venterea, and D. Tilman. 2009. Long-lasting effects on nitrogen cycling 12 years after treatments cease despite minimal long-term nitrogen retention. Global Change Biology 15:1755-1766.

Clark, C. M., and D. Tilman. 2010. Recovery of plant diversity following $\mathrm{N}$ cessation: effects of recruitment, litter, and elevated N cycling. Ecology 91:3620-3630.

Coffin, D. P., W. K. Lauenroth, and I. C. Burke. 1996. Recovery of vegetation in a semiarid grassland 53 years after disturbance. Ecological Applications 6:538-555.

Corbin, J. D., and C. M. D'Antonio. 2004. Can carbon addition increase competitiveness of native grasses? A case study from California. Restoration Ecology 12:36-43.

Daubenmire, R. 1959. A canopy-coverage method of vegetational analysis. Northwest Science 33:43-64.

Delgado, J. A., A. R. Mosier, D. W. Valentine, D. S. Schimel, and W. J. Parton. 1996. Long term $15 \mathrm{~N}$ studies in a catena of the shortgrass steppe. Biogeochemistry 32:41-52.

Emmett, B. 2007. Nitrogen saturation of terrestrial ecosystems: some recent findings and their implications for our concep- tual framework. Water, Air, and Soil Pollution: Focus 7:99109.

Eschen, R., S. R. Mortimer, C. S. Lawson, A. R. Edwards, A. J. Brook, J. M. Igual, K. Hedlund, and U. Schaffner. 2007. Carbon addition alters vegetation composition on ex-arable fields. Journal of Applied Ecology 44:95-104.

Eschen, R., H. Müller-Schärer, and U. Schaffner. 2006. Soil carbon addition affects plant growth in a species-specific way. Ecology 43:35-42.

Foster, N. W., E. G. Beauchamp, and C. T. Corke. 1985. Immobilization of nitrogen-15-labelled urea in a jack pine forest floor. Soil Science Society of America Journal 49:448.

Hobbs, R. J., and L. F. Huenneke. 1992. Disturbance, diversity, and invasion: implications for conservation. Conservation Biology 324-337.

Hook, P. B., and I. C. Burke. 1995. Evaluation of methods for estimating net nitrogen mineralization in a semiarid grassland. Soil Science Society of America Journal 59:831.

Hook, P. B., and I. C. Burke. 2000. Biogeochemistry in a shortgrass steppe landscape: control by topography, soil texture, and microclimate. Ecology 81:2686-2703.

Hook, P. B., I. C. Burke, and W. K. Lauenroth. 1991. Heterogeneity of soil and plant $\mathrm{N}$ and $\mathrm{C}$ associated with individual plants and openings in North American shortgrass steppe. Plant and Soil 138:247-256.

Johnson, D. W. 1992. Nitrogen retention in forest soils. Journal of Environmental Quality 21:1.

Johnson, D. W., W. Cheng, J. D. Joslin, R. J. Norby, N. T. Edwards, and D. E. Todd. 2004. Effects of elevated $\mathrm{CO}_{2}$ on nutrient cycling in a sweetgum plantation. Biogeochemistry 69:379-403.

Jonasson, S., P. Vestergaard, M. Jensen, and A. Michelsen. 1996. Effects of carbohydrate amendments on nutrient partitioning, plant and microbial performance of a grassland-shrub ecosystem. Oikos 75:220-226.

Lauenroth, W. K. 2008. Vegetation of the shortgrass steppe. Pages 70-83 in W. K. Lauenroth and I. C. Burke, editors. Ecology of the shortgrass steppe: a long-term perspective. Oxford University Press, New York, New York, USA.

Lauenroth, W. K., and I. C. Burke. 2008. Ecology of the shortgrass steppe: a long-term perspective. Oxford University Press, New York, New York, USA.

Lauenroth, W. K., J. L. Dodd, and P. L. Sims. 1978. The effects of water-and nitrogen-induced stresses on plant community structure in a semiarid grassland. Oecologia 36:211-222.

Lowe, P. N., W. K. Lauenroth, and I. C. Burke. 2002. Effects of nitrogen availability on the growth of native grasses exotic weeds. Journal of Range Management 55:94-98.

Magill, A. H., and J. D. Aber. 2000. Variation in soil net mineralization rates with dissolved organic carbon additions. Soil Biology and Biochemistry 32:597-601.

Maron, J. L., and R. L. Jefferies. 1999. Bush lupine mortality, altered resource availability, and alternative vegetation states. Ecology 80:443-454.

Mattson, S., and E. Koutler-Andersson. 1942. The electrochemistry of soil formation. V. A lysimeter study of podzolic solvation and precipitation. Lantbrukshogskolans Annaler 10:241-257.

Mattson, S., and E. Koutler-Andersson. 1943. The acid-base condition in vegetation litter and humus. VI. Ammonia fixation and humus-nitrogen. Lantbrukshogskolans Annaler 11:107-134.

McCulley, R. L., I. C. Burke, and W. K. Lauenroth. 2009. Conservation of nitrogen increases with precipitation across a major grassland gradient in the Central Great Plains of North America. Oecologia 159:571-581.

McGregor, R. L., and T. M. Barkley. 1986. Great Plains Flora Association. Flora of the Great Plains. University Press of Kansas, Lawrence, Kansas, USA.

Milchunas, D. G., and W. K. Lauenroth. 1995. Inertia in plant community structure: state changes after cessation of 
nutrient-enrichment stress. Ecological Applications 5:452458.

Morghan, K. J. R., and T. R. Seastedt. 1999. Effects of soil nitrogen reduction on nonnative plants in restored grasslands. Restoration Ecology 7:51-55.

Mortland, M. M., and A. R. Wolcott. 1965. Sorption of inorganic nitrogen compounds by soil materials. Soil nitrogen. Agronomy 10:150-197.

Nõmmik, H. 1970. Non-exchangeable binding of ammonium and amino nitrogen by Norway spruce raw humus. Plant and Soil 33:581-595.

Paschke, M. W., T. McLendon, and E. F. Redente. 2000. Nitrogen availability and old-field succession in a shortgrass steppe. Ecosystems 3:144-158.

Paul, E. A., and F. E. Clark. 1989. Soil microbiology and biochemistry. Academic Press, San Diego, California, USA.

Perry, L. G., D. M. Blumenthal, T. A. Monaco, M. W. Paschke, and E. F. Redente. 2010. Immobilizing nitrogen to control plant invasion. Oecologia 163:13-24.

Perry, L. G., S. M. Galatowitsch, and C. J. Rosen. 2004. Competitive control of invasive vegetation: a native wetland sedge suppresses Phalaris arundinacea in carbon-enriched soil. Journal of Applied Ecology 41:151-162.

SAS Institute. 1989. SAS/STAT guide for personal computers: Version 6 edition. SAS Institute, Cary, North Carolina, USA.

Schimel, J. P., and M. K. Firestone. 1989. Inorganic N incorporation by coniferous forest floor material. Soil Biology and Biochemistry 21:41-46.
Spiegelberger, T., O. Hegg, D. Matthies, K. Hedlund, and U. Schaffner. 2006. Long-term effects of short-term perturbation in a subalpine grassland. Ecology 87:1939-1944.

Stevenson, F. J. 1994. Humus chemistry: genesis, composition, reactions. John Wiley and Sons, New York.

Stevenson, F. J., and X. T. He. 1990. Nitrogen in humic substances as related to soil fertility. Pages $91-100$ in $\mathrm{P}$. MacCarthy, editor. Humic substances in soil and crop sciences: selected readings. Soil Science Society of America, Madison, Wisconsin, USA.

Szili-Kovacs, T. K. Török, E. L. Tilston, and D. W. Hopkins. 2007. Promoting microbial immobilization of soil nitrogen during restoration of abandoned agricultural fields by organic additions. Biology and Fertility of Soils 43:823-828.

Török, K., T. Szili-Kovacs, M. Halassy, T. Toth, Z. Hayek, M. W. Paschke, and L. J. Wardell. 2000. Immobilization of soil nitrogen as a possible method for the restoration of sandy grassland. Applied Vegetation Science 3:7-14.

Vinton, M. A., and I. C. Burke. 1995. Interactions between individual plant species and soil nutrient status in shortgrass steppe. Ecology 76:1116-1133.

Vitousek, P. M., J. D. Aber, R. W. Howarth, G. E. Likens, P. A. Matson, D. W. Schindler, W. H. Schlesinger, and G. D. Tilman. 1997. Human alteration of the global nitrogen cycle: sources and consequences. Ecological Applications 7:737750.

Zink, T. A., and M. F. Allen. 1998. The effects of organic amendments on the restoration of a disturbed coastal sage scrub habitat. Restoration Ecology 6:52-58. 